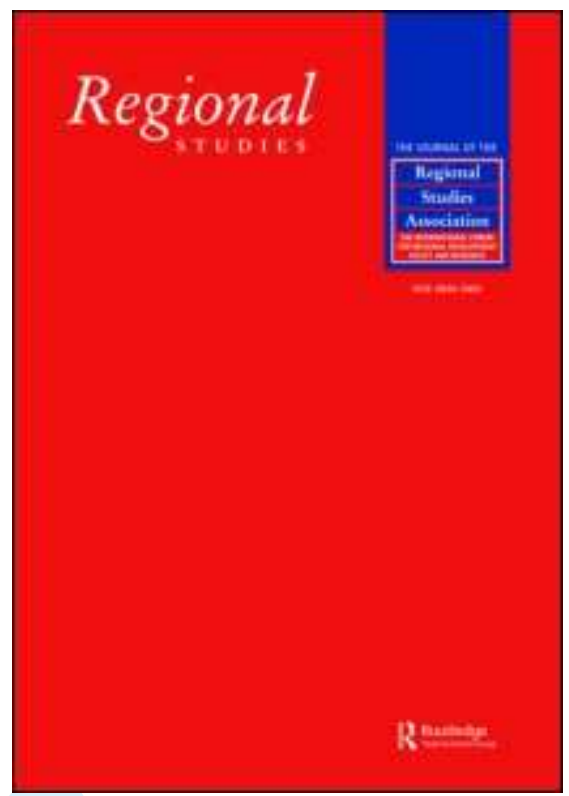

\title{
Limits to the Mega-City Region: Contrasting Local and Regional Needs
}

\begin{tabular}{|r|l|}
\hline Journal: & Regional Studies \\
\hline Manuscript ID: & CRES-2009-0057 \\
\hline Manuscript Type: & Main Section \\
\hline JEL codes: & $\begin{array}{l}\text { O18 - Regional, Urban, and Rural Analyses < O1 - Economic } \\
\text { Development < O - Economic Development, Technological Change, } \\
\text { and Growth, R11 - Regional Economic Activity: Growth, } \\
\text { Development, and Changes < R1 - General Regional Economics < R } \\
\text { - Urban, Rural, and Regional Economics, R23 - Regional } \\
\text { Migration|Regional Labor Markets|Population < R2 - Household } \\
\text { Analysis < R - Urban, Rural, and Regional Economics, R58 - } \\
\text { Regional Development Policy < R5 - Regional Government Analysis } \\
<\text { R - Urban, Rural, and Regional Economics }\end{array}$ \\
\hline Keywords: & \begin{tabular}{l} 
city-region, economic development, spatial planning, housing \\
\hline
\end{tabular} \\
\hline
\end{tabular}

\section{ScholaroNE \\ Manuscript Central}




\title{
Limits to the Mega-City Region:
}

\section{Conflicting Local and Regional Needs}

\author{
Ivan Turok \\ Urban Studies \\ Faculty of Law, Business and Social Sciences \\ University of Glasgow \\ 25 Bute Gdns Glasgow G12 8RS \\ United Kingdom \\ $\underline{\text { i.turok@lbss.gla.ac.uk }}$
}

Received March 2008, in revised form August 2008, Feb 2009, accepted March 2009

\begin{abstract}
There has been a revival of interest in the city-region in recent spatial planning and development policy. The economic arguments have been most prominent, while the environmental and social dimensions have been neglected. This paper analyses the tension within large or 'mega' city-regions between local needs and regional interests, using the UK's Thames Gateway initiative as an example. It has gained support as a plan to concentrate the supply of new housing in an area east of London in response to wider growth pressures and housing constraints. Yet the priority locally is economic and social development for existing residents rather than more housing for incomers. The paper explores the contrast between the regional housing agenda and the needs of established local communities for jobs, skills and improved services. It shows how the pursuit of narrow regional objectives may complicate the task of local regeneration. There are important lessons for city-region theory and practice in not constraining the role envisaged for secondary cities and towns in relation to the core city.
\end{abstract}

Key words: city-region; economic development; spatial planning; housing 
Ivan Turok

对巨型城市区域的制约：地方及区域需求的冲突, 区域研究。在目前的空间规 划与发展政策理论领域, 城市区域又重新成为了学术讨论的焦点。经济再度成 为讨论的主题而忽视了与环境、社会相关的问题。本文以英国泰晤士门户区为 例分析了大、巨型城市区域中地方需求与区域兴趣之间的张力。为了应对大范 围增长压力以及房屋需求制约, 一项针对东伦敦地区而提出的新房供应计划已 获支持。然而地方首要的需求并非为新居民提供更多住房, 而是在于促进现有 居民的经济及社会发展。文章探讨了区域住房议程与当地社区对于工作、技能 、提升服务水准需求之间的矛盾。研究指出, 为了实现具体的区域目标, 地方 更新任务变得愈加复杂。这也为在城市区域理论及实践中不限制预定二级市镇 之于核心城市的作用提供了重要借鉴。

Les limites de la mégacité-région: le conflit entre les besoins locaux et régionaux.

Turok

Récemment, l'aménagement du territoire a fait preuve d'un regain d'intérêt pour la cité-région. Le raisonnement économique a joué un rôle de premier plan, tandis que l'on n'a fait attention aux perspectives ni sociale, ni environnementale. A partir d'une étude de cas, à savoir la Thames Gateway, cet article cherche à analyser le conflit au sein des grandes ou des 'mégas' cités-régions entre les besoins locaux et les intérêts régionaux. Cette initiative trouve du soutien comme schéma directeur qui cherche à concentrer l'offre de nouveaux logements dans une zone à l'est de Londres en réponse à la demande de croissance et aux restrictions à la construction de logements. Toujours est-il que la priorité sur le plan local s'avère le développement économique et social pour les habitants existants plutôt que la construction de logements pour les nouveaux venus. L'article examine le contraste entre le programme régional quant au logement et la demande d'emploi, d'habilités et de meilleurs services des communautés locales. On montre comment la poursuite des objectifs régionaux limités peut compliquer la tâche de la régénération locale. Il y a d'importantes leçons a tirer pour les cité-régions en théorie et en pratique dans la mesure où il ne faut pas limiter le rôle prévu des grandes villes et des villes secondaires par rapport à la ville principale.

Cité-région / Développement économique / Aménagement du territoire / Logement

http://mc.manuscriptcentral.com/cres Email: regional.studies@newcastle.ac.uk 


\section{Grenzen der Megastadtregion: der Konflikt zwischen lokalen und regionalen Bedürfnissen}

Ivan Turok

In letzter Zeit hat sich in der Politik zur Raumplanung und -entwicklung das Interesse für die Stadtregion wieder belebt. Die wichtigste Rolle hierbei spielten die wirtschaftlichen Argumente, während die Umwelt- und sozialen Dimensionen vernachlässigt wurden. In diesem Beitrag wird die Spannung zwischen lokalen Bedürfnissen und regionalen Interessen innerhalb großer bzw. 'Mega'-Stadtregionen anhand des Beispiels der Thames-Gateway-Initiative in Großbritannien analysiert. Diese Initiative fand Unterstützung als Plan zur Konzentration des Wohnungsbaus in einem Gebiet östlich von London, mit dem auf den Druck für breiteres Wachstum und die Einschränkungen im Bereich des Wohnungsbaus reagiert wurde. Zugleich liegt jedoch die Priorität vor Ort statt im Bau zusätzlicher Wohnungen für hinzuziehende Anwohner in der wirtschaftlichen und sozialen Weiterentwicklung der vorhandenen Anwohner. In diesem Beitrag wird der Kontrast zwischen den regionalen Wohnungsbauplänen und den Bedürfnissen der vorhandenen Gemeinschaften vor Ort in den Bereichen Arbeitsplätze, Ausbildung und verbesserte Dienstleistungen untersucht. Es wird gezeigt, dass sich durch das Verfolgen enger regionaler Ziele die Aufgabe der lokalen Regeneration verkomplizieren kann. Hieraus ergibt sich als wichtige Lehre für die Theorie und Praxis der Stadtregion, dass die für die sekundären Städte in Bezug auf die zentrale Stadt vorgesehene Rolle nicht zu eng gestaltet werden darf.

Keywords:

Stadtregion

Wirtschaftsentwicklung

Raumplanung

Wohnungsbau

\section{Límites a la región mega-ciudad: el conflicto entre necesidades locales y regionales Ivan Turok}

En la reciente política de planificación y desarrollo espacial se ha observado una reactivación de intereses en la región metropolitana. Los argumentos económicos han sido más destacados mientras que las dimensiones medioambientales y sociales han sido ignoradas. En este artículo analizo la tensión en las grandes o mega regiones metropolitanas entre las necesidades locales y los intereses regionales usando como ejemplo la iniciativa británica en el estuario del Támesis. El plan ha obtenido un amplio apoyo para concentrar la construcción de nuevas viviendas en un área al este de Londres como respuesta a las presiones generales de crecimiento y las limitaciones de viviendas. Sin embargo, la prioridad a nivel local es el desarrollo económico y social para los residentes actuales más que construir más viviendas para recién llegados. En este artículo analizo el contraste entre la agenda regional de viviendas y las necesidades de las comunidades establecidas locales sobre trabajo, habilidades y mejora de servicios. Se demuestra que buscar objetivos regionales más estrechos puede complicar la tarea de la regeneración local. Estos factores son importantes 
lecciones para la teoría y práctica de la región metropolitana de modo que no debe limitarse el rol previsto para las ciudades y localidades secundarias con relación a la ciudad central.

Keywords:

Ciudad-región

Desarrollo económico

Planificación espacial

Vivienda

JEL classification: O18, R11, R23, R58

http://mc.manuscriptcentral.com/cres Email: regional.studies@newcastle.ac.uk 


\section{Introduction}

Interest in the city-region (CR) in UK planning and development policy has been rekindled after some three decades in abeyance (Eddington, 2006; HM Treasury, 2006, 2007, 2008; Parkinson et al, 2006). A series of reports from academics and think tanks have coincided with wider political and economic developments to revive CR thinking in spatial decision-making (NLGN, 2005; Harding et al, 2006; Jones et al, 2006; Marshall and Finch, 2006). One of the concept's apparent policy attractions today is that it seems to be relevant both to the goal of economic regeneration in the North and West of Britain as to the challenges of growth management in the South East (Harding et al, 2006; HM Treasury, 2006).

The CR is commonly defined as a city or group of cities within a wider territory that have a close, interdependent relationship (Parr, 2005; Davoudi, 2008; RodriguezPose, 2008). Different places perform distinct and complementary functions, and they therefore interact through commuting, trade, information or other flows. A useful shorthand description of this functional geography or market area is the economic 'footprint' of the city. It is widely argued that if policies towards spatial planning, infrastructure and service delivery are devolved to the CR level and coordinated across relevant local authority jurisdictions, they may improve the efficiency of labour and housing markets, streamline transport systems and generate economic spinoffs through increased productivity, knowledge spillovers and innovation (Scott, 2001; Hall and Pain, 2006; HM Treasury, 2006, 2008; Eddington, 2006). In other words, CRs are held to offer considerable potential for integrated development strategies for places that are functionally coherent rather than arbitrarily defined.

Putting a CR policy framework into place in the UK is proving to be more complex than originally envisaged. The process to date has been ad hoc, uneven and incremental, with continuing uncertainties about $\mathrm{CR}$ powers, resources and accountability mechanisms (HCCLGC, 2007). A novel feature is a heavy reliance on 'thin' institutions and voluntary arrangements for coordination, in contrast to a dedicated tier of government or other formal structures at the CR level, as occurred for example during the 1970s with the creation of the metropolitan county councils in England and regional councils in Scotland (DCLG, 2006a; Harding et al, 2006; HM Treasury, 2007). This approach reflects a desire to avoid the costs of organisational restructuring and to include a wider range of influential stakeholders, within and outside government, in decision-making. Another emerging feature of current practice is that investment is to be targeted on localities with the greatest economic 'potential', which is reminiscent of growth pole arguments. In the face of local resistance, new housing is also to be developed in particular parts of the region rather than spread around (HCCLGC, 2007; DCLG, 2008). Claims are still made that CR policies can promote the regeneration of run-down areas and reduce social and spatial disparities within and between regions (DCLG, 2008; HM Treasury, 2007, 2008).

Many of the issues and implications arising from the pursuit of CR ideas are only just emerging, as is clear from several of the other papers in this special issue. Although it has often been presented as a policy panacea for balanced and sustained regional development, the CR seems unlikely to provide a simple means of reconciling diverse 
economic, environmental and social objectives (Keating, 1998; Buck et al, 2005; Rodriguez-Pose, 2008). For example, economic growth pressures may demand a larger labour pool for the core agglomeration, longer distance commuting for the enlarged workforce and more business travel and trade between centres, all implying greater mobility, higher carbon emissions and more congestion, especially if the private car continues to dominate travel patterns (Wheeler, 2009). The distinctive character and socio-economic needs of individual localities may also get neglected with a shift in perspective to the CR level and greater emphasis placed on economies of scale and region-wide connectivity (Healey, 2009). In short, depending on how they are pursued, CR policies could potentially reinforce spatial inequalities and unsustainable development processes, rather than mitigate these tendencies (Jonas and Ward, 2007; Neuman and Hull, 2009).

The purpose of this paper is to assess the idea that there may be some drawbacks associated with a CR approach, particularly if the perspective is narrow or onedimensional. These consequences may be particularly clear in places that were not previously covered by this scale of planning framework. It is instructive to consider the Thames Gateway (TG) initiative in the South-East of England through a CR lens because it illustrates important features of CR thinking. TG is an ambitious plan to accelerate the supply of new housing because of shortages in and around London as a result of its recent economic dynamism and population growth. High house prices in the South East have been inflationary and undermined Britain's economic performance (Barker, 2004). In the past, government regional housing targets were distributed among localities within the region. However, local opposition to development across much of the South East means that the new plan seeks to concentrate new housing into an urban corridor stretching 40 miles eastwards from London, along with three other 'growth areas' (ODPM, 2003a). The scale of the TG initiative means it is of considerable national significance in the UK. It was also recently described as Europe's largest regeneration programme (NAO, 2007). Discussion of the TG to date has tended to focus on two issues: (i) the complex governance arrangements and (ii) difficulties in financing all the new infrastructure required (John et al, 2005; Raco, 2005; Urban Task Force, 2005; Gordon, 2006; Oxford Brookes University, 2006; NAO, 2007; HCCPA, 2007; Catney et al, 2008). The principal concern of the present paper is with the substantive policies, namely the nature of proposed development and its likely impact on the area.

\section{\{Figure 1 around here\}}

The analysis focuses in on the city of Medway, one of the largest urban areas in the greater South East located about 30 miles east of London and with a population of 250,000 . It is strategically positioned as one of six priority locations for development during the first phase of the TG (DGLG, 2007). Local socio-economic and environmental conditions are poor by the standards of the South East, and Medway has been somewhat bypassed by rising regional prosperity over the last decade (Parkinson et al, 2006, Medway Council, 2006a). Consequently, it is an important place in which to consider the impact of the TG initiative.

\{Figure 2 around here\} 
This paper illustrates how CR ideas can influence local development priorities and projects, and what the effects are on the ground in specific places and communities. In particular, it seeks to examine how a rather simple CR concept based on limited sensitivity to local circumstances can amplify tensions between local needs and regional growth interests. The evidence assembled for this analysis includes extensive secondary economic and demographic data and a wide range of policy documents and reports, supplemented by extended interviews conducted by the author with twenty senior decision-makers at local and regional levels (see Appendix 1 for details).

The paper is organised as follows. The first section discusses the meaning of the CR concept and the reasons for its appeal to policy-makers. Sections two and three analyse the contemporary economic and social situation in Medway and the challenges faced. The fourth section considers the history of the TG initiative in its regional context. Section five explores how the basic objectives are being applied in Medway and how regional growth pressures can shape local development priorities and complicate the challenges facing the existing community. The conclusion draws out some wider implications for CR debates and explains why the arguments about Medway may apply to other secondary cities and towns in CRs elsewhere, particularly where their economic role and locational advantages are circumscribed.

\section{Recent Interest in the City-Region}

There are at least four reasons for the burgeoning recent policy interest in the CR concept. One is the declining significance of the administrative and built-up boundaries of cities as a result of falling transport costs, rising mobility and the dispersal of households and business activity (Salet et al, 2003; Parr, 2005; Hall and Pain, 2006; Harding et al, 2006). Consequently, the spatial reach or sphere of influence of core cities has been expanding, development pressures on the surrounding countryside have been increasing and policy-making has been obliged to reflect the reality of growing cross-boundary flows and interactions, both physical and economic. All sorts of anomalies and mismatches are likely if policies and services are not aligned across administrative boundaries to take account of functional geographies and market realities - such as journeys to work, retail catchments, and leisure and entertainment patterns. The gradual extension of the urban field and the desire to incorporate or cooperate with adjacent jurisdictions also reflects the continual search for greater efficiencies in the provision of many public and private services (DCLG, 2006a; Healey, 2009). This has to be balanced against the need for a close relationship between service providers and users, especially for personal and household services that are inherently local.

A second influence is the recognition that central government is too remote and unwieldy for the effective planning and delivery of certain functions (DCLG, 2006a; OECD, 2006; HM Treasury, 2007; Rodrigues-Pose, 2008). Decentralised institutions are more responsive to local and regional circumstances and better placed to set priorities in line with local needs and development potential (HCCLGC, 2007; DCLG, 2008). The CR is particularly important for the coordination and integration of strategic land-use, transport and other bulk infrastructure decisions because of the intensity of everyday flows at this scale and the disruptive effects of inconsistent or contradictory decisions (Eddington, 2006; Wheeler, 2009). Economic growth may be held back if a CR isn't functioning well because of traffic congestion, bottlenecks in housing supply or basic infrastructure deficiencies, such as inadequate water or power 
supply, or insufficient capacity for waste disposal. European spatial planning ideas and initiatives have also been influential, with similar themes of policy integration and coherent territorial organisation reflected in the notion of the 'polycentric urban region' (Davoudi, 2003; Faludi, 2006; Turok and Bailey, 2004; Hall and Pain, 2006). This is usually defined as a particular type of CR without a dominant city. There is more emphasis on balanced development across dispersed urban centres, rather than concentrated growth in the core city. Spatial policy may deliberately encourage investment in secondary centres in order to spread income and employment from the leading city and create viable counterweights or 'sustainable settlements' elsewhere.

The third and perhaps most important current reason for pursuing the CR model is that it reinforces the economic advantages of agglomeration, including business access to a deep labour pool, diverse suppliers, specialised services and good external connections (Turok, 2004; HM Treasury, 2006, 2008; Rice et al, 2006). Firms can 'mix and match' their inputs and alter their workforce more easily in response to changing technology and business needs (Buck et al, 2005). This flexibility lowers costs, raises productivity and improves economic resilience. Knowledge-intensive activities may benefit from proximity to universities and greater circulation of information and ideas, generating superior learning and innovation (Braczyk et al, 1998; Audretsch and Feldman, 2004; HM Treasury, 2006; Jones et al, 2006). Policies made at CR level should be able to incorporate a fuller range of strategic economic assets beneficial to competitiveness than local policies, and be better placed to promote institutional collaboration, sharing of resources and labour market matching (DCLG, 2006a; HM Treasury, 2006). This is a popular argument in the expansive 'super-region' or 'mega-city region' of the greater South East, as well as in some other metropolitan regions in Europe and further afield (Hall and Pain, 2006; Gordon, 2006; Scott, 2001; Salet et al, 2003). It reflects a view that large city-regions or 'super-agglomerations' are emerging all over the world as the engines of the contemporary global economy in what may amount to a new phase in capitalist territorial development (Scott and Storper, 2003; see also Hall and Pain, 2006).

Finally, the CR agenda could fill the lacuna left by the Government's stalled regional devolution project in the North and West of England (Parr, 2005; Gonzalez et al, 2006; Harding, 2006; HCCLGC, 2007; Healey, 2009). The CR is sufficiently flexible to cover many different kinds of places with a variable outer boundary depending on the defining criteria and thresholds applied (Harding et al, 2006). In principle, it appeals to the interests of cities as well as surrounding towns and rural areas, encouraging investment in improved transport links between such settlements, enabling places to tap into growth occurring in neighbouring areas and 'borrow' the advantages of agglomeration by combining resources and avoiding duplication. It has also been linked to the urban regeneration agenda through the need to set clearer objectives and priorities for public investment and to connect deprived communities with economic opportunities elsewhere (DCLG, 2008). The emphasis on selectivity and functional specialisation means that places have to think through their distinct qualities, economic roles and relationships with other towns and cities. This conforms with the prevailing approach to tackling regional inequalities in focusing on indigenous growth and self-sufficiency, rather than diverting investment from prosperous regions and other forms of resource transfer (Fothergill, 2005). The renewed interest in CRs is therefore consistent with what has been widely described as the 'new regionalism' (Keating, 1998; Pike et al, 2006). 
Although it is not a tightly-defined concept and is open to different interpretations, many of the arguments for CRs tend to imply that higher levels of internal connectivity within the $\mathrm{CR}$ are beneficial, and that the bigger the $\mathrm{CR}$ the better, especially for economic competitiveness. This helps to explain the popularity of terms such as 'global city region', 'mega-regions' and 'polycentric mega-city-region' (Scott, 2001; Hall and Pain, 2006; Hall, 2009). The justification for CRs in the UK has arguably been rather narrow and the policy agenda somewhat restricted in scope, being dominated by concerns about economic growth and efficient public spending (Davoudi, 2008; Healey, 2009; see also HCCLGC, 2007; HM Treasury, 2008). The environmental aspects have generally been neglected, along with the consequences for localities that are disadvantaged or by-passed for whatever reason in a more open, competitive regional context, where public resources are allocated more selectively. There are also unresolved questions in the discussion of CRs about the appropriate relationship between regional and local decision-making, and risks that regional priorities will override local concerns in enlarging the scale of territorial planning. This was one of the issues that the sub-national review of economic development and regeneration sought to address, although without a simple resolution (HM Treasury, 2007).

Before turning to the case study, four basic themes or questions can be drawn out of this discussion to provide a framework to guide the empirical analysis. First, how strongly connected is the particular city or town to the wider functional area? The linkages may take different forms (commuting, trade, information, etc), but for a secondary city or town to be planned as part of a CR, one would expect reasonably strong flows or interactions with the core city. Second, what is the nature of the relationship between the secondary city and the core city? Is it a fairly balanced relationship with mutual dependence between places, or an unequal situation with the core city benefitting disproportionately from the quantity and quality of investment, employment and incomes? Third, how do social conditions in the secondary city compare with the wider CR, in terms of the welfare of the local population, level of education, social infrastructure and amenities, social fabric, civic pride and identity, summed up as 'social cohesion'? Finally, what are the environmental implications of the secondary city being part of the wider CR, in terms of the nature and quality of transport connections, level of congestion and carbon emissions, and the "quality of place' - its functional coherence, built environment and physical infrastructure? Taken together, these questions get to the heart of how effectively a particular city is integrated into a wider CR.

\section{The Medway Context: A Porous Economy}

Situated at the heart of the TG, Medway is made up mainly of a continuous built-up area comprising the five historic towns of Chatham, Rochester, Gillingham, Rainham and Strood that have coalesced over the years (figure 3). Medway Council is a unitary (single tier) authority and was created in 1998 by the amalgamation of two lower tier councils (Rochester and Gillingham). For many years the local economy was quite self-contained and dominated by the Royal Naval Dockyard at Chatham and other port-related industries. The Dockyard's closure in 1984 and concurrent deindustrialisation destroyed many manual jobs and left a legacy of derelict and contaminated land. Subsequent recovery has been slow and patchy, resulting in very 
low household incomes and productivity compared with regional and national averages (Table 1).

\section{\{Figure 3 around here\}}

\{Table 1 around here\}

The local economy also differs from the wider region with fewer jobs in high value industries. There are 20\% fewer jobs in finance, IT and other business services than in the South East region as officially defined (i.e. excluding London and the East of England) and $17 \%$ more jobs in public administration and health (Appendix Table A1). Only 35\% of Medway residents are employed in professional, managerial and technical occupations, compared with $47 \%$ in the wider region (Appendix Table A2). Medway's social composition is unusual for the South East, reflecting its industrial history and position in the regional housing market.

Economic weakness has forced many residents to look elsewhere for work, including London. Through out-commuting the employment rate has recovered from the 1980s nadir and is not as far below the regional average as one might have expected (Table 2). Nevertheless, there are sizeable numbers on welfare benefits and many inactive people who want to work, suggesting disguised unemployment (Table 2). Youth unemployment is particularly high, perhaps because young people are less inclined to commute or lack relevant skills.

\section{\{Table 2 around here\}}

A useful way of characterising Medway's recent evolution is towards a more porous or 'leaky' economy. The evidence presented below suggests that resources (financial and human) flow into and out of the area with weaker local circulation and propensity to 'stick' than in other settlements of comparable size. This affects the quality of local amenities and infrastructure, including the public realm and transport system. It means that Medway has less functional integrity, and therefore attractiveness, as a place to live, work, study and socialise than many other cities. This is highly relevant to the discussion later in the paper about the impact of policy efforts to insert it more deliberately into the $\mathrm{CR}$ through the TG proposals for substantial additional housing in the area.

For example, the ratio of total employment to the working-age population (the 'jobs density') is only 0.68. In other words there are about two jobs available for every three adults of working age. The figure for the official South East (excluding London) is 0.88 , suggesting a sizeable jobs deficit in Medway. Appendix Table A3 shows that the jobs density for other places that are loosely comparable in terms of size and distance from London varies between 0.71 and 1.17. It is not a perfect comparison because the statistics are based on administrative boundaries, which are tighter in some places than in others. Yet it does seem that Medway has a bigger shortfall in employment than other cities in the region.

Medway 'exports' more than two out of five (41\%) working residents. Nearly 48,000 people commute elsewhere to work compared with less than 19,000 who commute into Medway (Appendix Table A4). The average distance Medway residents travel to work is $17.5 \mathrm{~km}$, compared with $14.9 \mathrm{~km}$ in the whole region, $15.6 \mathrm{~km}$ in Brighton, 
$14.1 \mathrm{~km}$ in Milton Keynes, $11.4 \mathrm{~km}$ in Portsmouth and $10.9 \mathrm{~km}$ in Southampton. This implied link between a lack of jobs and long distance commuting is supported by a recent study of South East commuting: "a lack of job opportunities close to the place of residence was a strong feature of longer commutes" (Titheridge and Hall, 2006, p.74). According to key informants in the present study, commuters incur a heavy personal cost in travel time and fatigue, weakening the community, as discussed later. Long commutes also exacerbate transport congestion, energy consumption and carbon emissions (Lucas, 1998).

Commuting patterns are strongly influenced by occupation. More than half $(53 \%)$ of local residents who commute to London are professionals, managers and employers, compared with only $29 \%$ of people who both live and work in Medway (Appendix Table A4). This is not unusual because highly skilled, well-paid workers normally commute further on average than people in other occupations (Harding et al, 2006; Titheridge and Hall, 2006). Conversely, only $12 \%$ of commuters to London are in routine and semi-routine occupations, compared with $33 \%$ of people who live and work locally. The skewed composition of out-commuting is also reflected in incommuting (Appendix Table A5).

The need to commute elsewhere is matched by a propensity for residents to consume elsewhere too. There seems little doubt among key informants that local retail and leisure facilities are inferior to many other places: "Many of Medway's centres suffer from a negative image" (Medway Council, 2006a, p.16). This is both a symptom and a cause of household spending outside the area, including at Britain's largest regional shopping mall 'Bluewater' near Dartford. Considerable spending on entertainment, recreation and related services also occurs in London.

Cities of Medway's size normally function as regional service centres with a sizeable professional and financial sector and high order social and cultural facilities. Proximity to London, poor internal connectivity and a truncated hinterland resulting from a coastal location hamper Medway's ability to operate as a dynamic hub of activity attracting and spawning different consumer and business services. Instead it seems more like five independent dormitory towns adjacent to each other and largely by-passed by the consumer boom and general high street revival of the last 15 years.

Medway has features that have always attracted visitors, including the second oldest cathedral in England, a Norman castle, the historic Dockyard and a Charles Dickens connection. Yet, most are day visitors on coaches because of the limited hotels, restaurants and related facilities. The River Medway also accommodates several large marinas with many pleasure boats and yachts, but most are owned by people living elsewhere who take advantage of the cheap berths and spend little time or money onshore. The lack of quality services to detain people for longer means that Medway has a relatively small share of jobs in tourism, despite its rich history and recreational assets (Appendix Table A1).

Until recently there was no local university, raising concerns that Medway was losing out from learning opportunities for school leavers and the economic stimulus and status that other places derive from universities (OECD, 2007). With external funding, the universities of Greenwich and Kent established a joint satellite campus in Chatham. Yet, only one in eight of the first 2500 students came from Medway itself. 
Most of the others were commuting from London on a daily basis, against the prevailing traffic flow. Efforts to improve ancillary social and sports facilities may encourage more students from elsewhere to come and live locally and more local school leavers to go to university. A local MP suggested that a more prestigious university might have a bigger impact in this respect (HCCPA, 2007).

Medway's porous economy is reflected in its physical structure. The five towns lack a focal point for the transport network that could have become a viable city centre. Instead there are four separate high streets, three municipal centres and five railway stations. External connectivity has improved over time, but this may have made the economy more permeable rather than increased inward investment. Given its strategic location between London and the Channel ports, one might have expected greater buoyancy. Unhelpful external perceptions, the long distance to an international airport and poor workforce skills (see below) seem to have discouraged investment. Other towns in Kent are benefitting more from the high speed Channel Tunnel Rail Link, particularly Ashford and Ebbsfleet as the sites of new stations (Hall and Pain, 2006). A strong regeneration case could have been made for routing the CTRL through Medway. This was a significant missed opportunity.

\section{Medway's social context: challenges of cohesion}

There are other towns in the greater South East with porous economies and outcommuting. However, they tend to be desirable residential locations with high quality housing that function as dormitory areas for London. Competition to live there is reflected in high house prices and high incomes. Industrial and commercial development is restricted to protect the environmental amenity. People choosing to live there accept the need to commute elsewhere to work and can afford to do so. Such places have been functionally integrated into the wider CR for longer and with more success.

Medway is a different kind of place. Apart from lower incomes (Table 1), house prices are only $68 \%$ of the regional average: "This is a stark reflection on Medway's poor image, connectivity and economic performance" (Medway Council, 2006b, p.7). Much of the social housing stock is in poor condition and requires renewal or replacement. Human capital is also relatively low. Only $18.3 \%$ of adults have a degree or HND (NVQ4 and above), compared with 30.5\% in the official South East (see Appendix Table A6). One in eight have no qualifications at all. Traditional industries preferred apprenticeships rather than formal education, which meant that 'learning' and 'earning' were not strongly linked in local working class culture.

Economic difficulties have created a range of linked social problems more typical of Northern industrial cities (Turok et al, 2006). Many interviewees described a certain malaise within the community, including loss of civic pride, depressed expectations and a weak social fabric with many households vulnerable to domestic disputes, family breakdown and educational disaffection among children. Extensive commuting deprives Medway of community vitality and self-organisation through commuters' inability or unwillingness to contribute to school parent associations, youth projects, charities and other civic activities. Youth services are generally under-funded, including learning and cultural facilities, leisure and sports amenities and detached youth workers. Responding to incidents of anti-social behaviour is a higher priority than constructive work with young people. 
Medway's health record is also poor (Medway Council, 2006b). High teenage pregnancy is associated with low expectations and poor prospects for working class girls. Primary care is dominated by stand-alone GPs, whose recruitment is complicated by London's shadow effect, as is the case with teachers and some other professionals. Medway lacks community-based services offering integrated health care, family advice, children's services, community nurses and anti-smoking programmes.

\section{The Thames Gateway initiative}

Medway is the largest of several towns along the Thames Estuary facing similar challenges of deprivation, decay and damaged reputations (NAO, 2007). The subregion was not a regeneration priority for many years because conditions were worse in Inner London. The first government recognition of the problem was in 1967 when the South East Economic Planning Council identified the area as requiring attention in their Strategic Plan (Church and Frost, 1995; Lucas, 1998). The subsequent version of the Plan confirmed south Essex as one of five planned growth areas in the South East.

These plans had little real impact and the origins of the actual TG initiative can be traced to early-1980s local authority lobbying in north Kent in the face of industrial job losses and out-migration, together with perceptions of neglect by the rest of Kent (Church and Frost, 1995; Hull, 1998). The London Planning Advisory Committee drew a connection between the depressed conditions East of London and the buoyant West. They raised the possibility of altering the balance, partly to alleviate congestion and overheating in the West. This was pursued by the London and South East Regional Planning Conference (SERPLAN) in its 1987 guidance to the government. SERPLAN proposed an East Thames Corridor (ETC) as a focus for development, including major regeneration sites requiring reclamation and improved infrastructure. It said the ETC would also need a stronger identity to attract private investment.

In the early 1990s government became more interested in the potential of the ETC to redress the regional economic imbalance (Hull, 1998; Lucas, 1998). Studies were commissioned that confirmed significant development opportunities, subject to public investment in transport and land improvement. Under Michael Heseltine the idea gained a high profile, indeed it became central to his political ambitions (Rydin, 1998). He re-branded it Thames Gateway - a key strategic link between the UK and Europe, reinforcing London's position as a World City (Church and Frost, 1995; NAO, 2007). However, the case was not compelling at a time of economic slowdown, and the Treasury refused the support needed for a major regeneration programme (Rydin, 1998). Creating an economic counter-magnet to the West of London required a degree of coordinated public sector action that was unfashionable at the time. The ethos of the government was about enabling market forces rather than steering them in particular directions.

Instead the mid-1990s was characterised by a series of separate, mostly low key projects in the TG. It was decided to work in partnership with the local authorities, rather than set up a special urban development corporation (UDC) and risk repeating the conflict created in the London Docklands and elsewhere during the previous decade. The national land renewal agency English Partnerships began to invest in site assembly and remediation in Medway and elsewhere. Several transport schemes 
acquired a higher priority as a team of civil servants tried to skew resources towards the TG. Parts of the corridor were given assisted area status and became eligible for regional aid and European structural funds. Several TG localities also bid successfully for projects under the Single Regeneration Budget. "At that point, the focus was very much upon economic regeneration and the creation of employment for some of the most impoverished communities in the south east" (Harding et al, 2006, p.55).

Meanwhile, housing pressures were building up in the South East, partly because of London's resurgence coupled with vigorous opposition to new development. Advisers began to suggest that the TG "offers the only part of the Region where land needs primarily for housing - can be met without major, expensive, delaying and politically damaging controversy" (Crookston, 1994, p. 11). Church and Frost referred to the TG as "a safety valve for the next boom in the South East" (1995, p.208). This perspective was clearly giving priority to regional housing interests above the local regeneration needs that had been articulated previously. To deliver large-scale housing required substantial government investment in transport, land reclamation and other infrastructure. Concerted efforts were also required to enhance the image and appeal of the area if it was to attract private investors, developers and above all households from elsewhere in the South East.

As regional growth constraints increased into the new millennium, the demands for stronger government action mounted. The Barker Review was particularly influential in making the case for a step change in housing supply (Barker, 2004). The 2003 Sustainable Communities Plan was the immediate response, reflecting the need "to accommodate the economic success of London and the wider South East and ensure that the international competitiveness of the region is sustained" (ODPM, 2003a, p. 46). The TG was one of four 'growth areas' identified for 200,000 extra homes above existing plans by 2016 (Figure 1). Indicating high level government support, the TG was allocated almost three-quarters of the initial five-year $£ 610 \mathrm{~m}$ funding for site assembly, remediation and infrastructure, because it was better prepared to absorb the additional housing capacity, having been a priority area for longer. A target of 120,000 new homes was set by 2016, 40,000 above the existing regional planning figure. The term 'sustainable community' was introduced to indicate the aspiration, in principle at least, to create well-serviced, energy-efficient, thriving places rather than sprawling dormitory settlements.

The TG was officially described as a "huge opportunity" for five reasons: its sheer scale, proximity to London, good transport links to the continent, many brownfield sites and, lastly, the opportunity to regenerate existing deprived communities (ODPM, 2003a, p.52). A subsequent report confirmed that the TG "represents outstanding potential to expand housing supply close to London" (ODPM, 2003b, p. 9). These reports also indicated some ambitious job targets, but no justification was offered and no indication given of how they might be achieved. There was an acknowledgement in one report that: "We need to take account of the impact on existing communities" (ODPM, 2003b, p.5), but again no elaboration at all of what this meant in practice. In response to subsequent evidence of accelerating population growth in London, fuelled partly by international migration, the Government raised the housing target again in 2006 by 40,000 to a total of 160,000 homes by 2016 (DCLG, 2006b). In a keynote speech to the TG Forum the Minister Ruth Kelly reiterated the emphasis: "Our aim is to build homes, not houses. Create communities, not conurbations" (Kelly, 2006). 
Such statements support Cochrane's contention that: "What is being promised is the creation of new 'communities', rather than the organic development of existing communities" (2007, p. 54). Subsequent NAO and HCCPA inquiries were highly critical of the TG's vague targets and weak procedures. On the issue of who would benefit, the HCCPA concluded that: "There is a risk that the economic benefits of regeneration will not reach existing residents ... (and) that improved public services, infrastructure and housing will be concentrated in new developments" (2007, p. 6-7).

Local authorities generally welcomed the TG initiative as "an opportunity to direct much needed resources to their areas" (Raco, 2005, p.150). They felt in no position to challenge the government's basic priorities for what was "now primarily a housingbased programme" (Harding et al, 2006, p.56), believing that the investment would have a catalytic effect in their areas. In Medway, there was remarkably little debate in the local media or elsewhere about the strategy being pursued, reflecting the low level of civic engagement and perhaps a sense of desperation to see investment of any kind. A variety of local special purpose vehicles with varying powers were introduced across the TG to help deliver the scale of change expected, including the complex tasks of brownfield land assembly, site preparation and infrastructure provision. Unlike the earlier UDCs, they were required to work in partnership with local authorities (NAO, 2007). In Medway the government agreed to the council having a larger role in delivery because they had some prior experience and endorsed the strategy.

To summarise this section, the priorities for the TG shifted during the 1990s from its intrinsic regeneration needs towards its potential to deliver a wider regional agenda. At first the interest was in economic development and relieving growth pressures West of London. The focus subsequently changed to alleviating housing shortages throughout the greater South East. It was this housing role that gave the TG initiative momentum by unlocking substantial government investment and high level cabinet backing. It was also recognised that environmental improvements would be needed to attract incoming households with a choice of where to live. Use of ambiguous terms such as regeneration and sustainable communities helped to disguise some of the tensions and differences of purpose behind the initiative.

\section{The implications for Medway}

The Sustainable Communities Plan stated that at least 10,000 new homes would be built in Medway by 2016 (ODPM, 2003b). This was subsequently raised to 16,000 , with the population expected to increase by no less than 50,000 (20 per cent growth). The scale of vacant and derelict land made Medway an attractive location for the government. Its capacity to accommodate substantial new housing on brownfield sites was far more important than its social needs in securing special attention. The council was granted $£ 95 \mathrm{~m}$ to lay the foundations for accelerated redevelopment. A series of regeneration projects was proposed under the umbrella of the Medway Waterfront Renaissance Strategy. A dedicated delivery unit 'Medway Renaissance' was established to plan and coordinate these schemes. Government support also stirred renewed interest in the area from private investors and property developers. A major urban regeneration specialist (St Modwen Properties plc) was subsequently selected as Medway's 'investment partner' in a joint venture to deliver much of the 
redevelopment and lever in $£ 1$ billion of private funding on the basis of shared costs and profits.

The main physical projects are mapped in figure 3 and summarised in figure 4 . They are at various stages of master planning, site acquisition, land preparation and building construction. Much of the first few years has been devoted to preparing development frameworks and planning briefs, so some of the details are still uncertain. Nevertheless, the emphasis on new housing is immediately apparent. Commercial uses also feature, particularly retail and leisure. The special government grant was conditional on the delivery of new homes. With house-builders interested in buying vacant sites, the council as planning authority found it difficult to safeguard land for employment uses, especially as this is lower value than housing. The large sites at Rochester Riverside, Strood Riverside, Chatham Dockyard and Gillingham (Akzo Nobel) were major employment locations not long ago, but they are all now becoming mostly housing. Housing is the main use that produces the returns required to fund or at least offset the up-front costs of clearance works, remediation, flood protection and piling.

\section{\{Figure 4 around here\}}

There is some recognition that land is required for employment uses, but resources have not been committed to this and the council has been unwilling to release any lower amenity greenfield sites on the city fringe that the private sector might develop for this purpose. Table 3 shows the dominance of housing in future investment expectations, with economic development well down the list, below culture and on a par with environment and sports and leisure. Medway has supported light industrial estates in the past - Gillingham Business Park and City Estate on the north bank - and provided flexible units for small enterprises. However, there has been little of this activity recently. A range of speculative office buildings were constructed in Chatham in the 1990s in an effort to attract corporate headquarters and financial services, with mixed results.

\section{\{Table 3 around here\}}

The economic impact of the new housing is crucial to judgements about the benefits of TG to Medway. There will be many temporary jobs in construction, although the nature of this industry means that few will probably go to local workers unless special training and recruitment deals are negotiated with contractors (HCCPA, 2007). The permanent jobs generated by the new household spending on services should be more significant. The scale will depend on household composition, and there will be difficult trade-offs in this respect. The biggest impact should come from attracting people from elsewhere with high disposable incomes, but they may be the most difficult to attract because of the area's reputation (Bennett and Morris, 2006). There will be pressure from government to accommodate lower income households from London in order to alleviate its housing needs (HCCPA, 2007). There will also be local pressure to make a share of the new housing accessible to Medway residents.

The local employment multiplier should increase over time if perceptions change, the population expands and local services improve. These jobs will tend to reproduce the existing employment structure through more public services and relatively low value 
personal and consumer services. They will not add greatly to higher value or externally traded activity. A larger resident workforce will also mean more competition for emerging vacancies. All things considered there is no guarantee that the job prospects of existing residents will improve. Experience elsewhere casts doubt on the benefits of housing-led regeneration for employment and deprivation: "addressing poor housing will not lead to a lasting improvement in deprived areas if problems of worklessness and under-performing local economies are not also dealt with" (PMSU, 2005, p.17; see also Lupton, 2003; Kintrea, 2007). The sub-national review of regeneration and the subsequent regeneration framework endorsed a much stronger focus on economic development (HM Treasury, 2007; DCLG, 2008).

Most of the new projects are concentrated along the waterfront and in Chatham Maritime. The impact could remain localised and leave other areas behind, without stimulating a wider revitalisation of the city or improving its functional coherence. There may be pressure from the developers (and some sections of the council) to create places that are clearly distinct from established neighbourhoods in order to attract higher income households. A recent housing development on St Mary's Island provides grounds for this concern, as does the gated community at New Road in Rochester. Much depends on the council's attitude towards secluded development and its commitment to integrate new schemes into the existing urban fabric. The task is complicated by the finite resources available and the major investment required to upgrade established neighbourhoods and high streets. There is also pressure from government to deliver the new housing as quickly as possible (HCCPA, 2007; NAO, 2007). But obtaining synergies from the separate projects and avoiding a piecemeal approach will be vital to capture wider benefits for Medway.

Integration of new and old is a social and economic as well as a physical process. It is likely to require a series of practical mechanisms to link emerging opportunities to existing residents. Some involve developing skills, confidence and recruitment channels for people to compete for jobs. Others involve capacity building and procurement arrangements for local firms to get business contracts. Improved community infrastructure and services are important to tackle underlying social concerns. And greater consultation with existing communities is needed to respond to their fears and aspirations. Table 3 suggests that a reasonable level of investment in learning and skills is expected. However, the resources anticipated for social and community regeneration are perfunctory.

\section{Conclusion}

The CR has become an influential idea in spatial planning and development policy. It gives explicit recognition to the interactions between localities within a region and encourages strategic decisions to be made at an appropriate spatial scale. Coordination or integration is an important principle - between cities, towns and rural areas; across different levels and functions of government (such as land-use planning, transport and other infrastructure); and between economic, social and environmental objectives. In practice, the economic arguments have been most prominent in recent UK policy, implying that the CR should be treated as a large, well-connected functional system that promotes growth through agglomeration economies. This approach is convenient in apparently endorsing house-building in places where there is less local resistance to new development, rather than where the housing constraints are greatest, as long as a case can be made that they are part of the same functional area. However, this is not 
necessarily in the best interests of the recipient communities, which may need a broader-based approach to regeneration, including economic and social development.

It is useful to look at the TG initiative through a CR lens because it illustrates the contrast between local and regional agendas in concentrating a big increase in the supply of housing in order to meet growth pressures across the greater South East. It was chosen as a priority area mainly because brownfield sites were available and the local authorities were receptive to development. Depending on its success at attracting new households, the working population could increase substantially, many of whom will have to commute to London and elsewhere to work. Yet, the priority afforded to new housing does not correspond with the needs of existing residents for additional employment, skills and community services. The emphasis on housing complicates the task of job creation in reducing the supply of employment land. Medway has a porous economy and already functions as a dormitory area. This is not conducive to the overall health of the community and the integrity and quality of the city. More commuters will add to these concerns and put more pressure on stretched public services. If local regeneration was the top priority, there would be more focus on addressing economic and social weaknesses directly and less on using the location as a container for wider purposes and hoping for local benefits to permeate through.

It is not surprising that local decision-makers have grasped the opportunity to secure investment from the TG initiative. Despite the discrepancy between regional and local priorities, there is scope to generate spin-offs for the area. Experience elsewhere suggests that close involvement in the redevelopment process by local authorities is important in this respect. Through their financial resources and planning controls they have power to negotiate improvements to the public realm by developers and employment and training opportunities for residents. They can also make the case for additional government support to absorb the impact of population growth on existing services and transport infrastructure. This will require a clear sense of purpose, an improved evidence base and determination to maximise the TG's contribution to Medway's future prosperity.

The TG experience is not unique, but is relevant to other secondary cities and towns requiring revitalisation in CRs elsewhere. Places with a legacy of deindustrialisation or other locational disadvantages need forms of planning and investment that are responsive to local needs and circumstances, without neglecting the potential offered by the wider regional context for linking into external opportunities. While local planning policies devoid of wider context risk being insular and inward-looking, a narrow CR approach reflecting mainly regional interests can complicate the task such places face by reinforcing some of the weaknesses in the local economy and society, including the tendency to dormitory town status with weak local amenities, infrastructure and 'sense of place'.

Finally, this analysis has wider implications for the theory of CRs and its practical application in planning and development policy. It identifies a potential divergence between local and regional interests, and a risk that the needs of individual localities may get overlooked with the shift to a larger spatial scale of planning. Conventional CR concepts tend to neglect this possibility in emphasising the benefits of scale economies and intense flows of people, information and resources between places. The analysis cautions against an oversimplified distinction between the core city and 
an undifferentiated hinterland, in which new housing for commuters can be located almost anywhere and connectivity is key. There are costs associated with a high degree of functional differentiation across very large CRs, particularly the concentration of housing in outlying areas with inadequate infrastructure and continued reinforcement of the core city as the only viable economic location. This may foster imbalanced and unsustainable development.

Places outside the core city have the potential to perform a variety of productive roles arising from their lower business costs, less congestion, distinct skill-sets and availability of land and green space. These include light industry, logistics, shared business services, call centres and development of new environmental technologies, renewable energy sources and low carbon goods and services. They can also serve as important consumption centres for the wider region, including leisure, recreation, entertainment and education. A balanced CR perspective can help such places to identify economic functions that complement those of neighbouring cities and towns, and thereby benefit from the prosperity of the wider regional economy. This is more consistent with the concept of a polycentric CR than a monocentric CR. To develop this kind of approach requires local and regional interests both to be represented in governance arrangements, with mutual respect shown for their different needs and constituencies.

\section{References}

Audretsch, D. and Feldman, M. (2004) 'Knowledge spillovers and the geography of innovation', in Henderson, J. and Thisse, J (eds) Handbook of Urban and Regional Economics, vol.4. pp. 2713-2739.

Barker, K. (2004) Review of Housing Supply. Delivering Stability: Securing our Future Housing Needs, London: HM Treasury.

Bennett, J. and Morris, J. (2006) Gateway People: The aspirations and attitudes of prospective and existing residents of the Thames Gateway, London: IPPR.

Braczyk, H., Cooke, P. and Heidenreich, M. (eds) (1998) Regional Innovation Systems, London: UCL Press.

Buck, N., Gordon, I., Harding, A. and Turok, I. (2005) Changing Cities: Rethinking Urban Competitiveness, Cohesion and Governance, London: Palgrave.

Catney, P., Dixon, T. and Henneberry, J. (2008) 'Hyperactive governance in the Thames Gateway', Journal of Urban Regeneration and Renewal, 2, 2. pp. 124-145.

Cochrane, A. (2007) Understanding Urban Policy: A Critical Approach, Oxford: Blackwell.

Crookston, M. (1994) 'East Thames Corridor', lecture to RICS CPD course, University of Westminster.

Church, A. and Frost, M. (1995) 'The Thames Gateway - an analysis of the emergence of a sub-regional regeneration initiative', The Geographical Journal, 161, 2, pp. 199-209.

Davoudi, S. (2003) 'Polycentricity in European spatial planning: from an analytical tool to a normative agenda', European Planning Studies, 11, 8, pp. 979-999.

Davoudi, S. (2008) 'Conceptions of the city-region: A critical review', Urban Design and Planning, 161, 2. pp. 51-60.

Department for Communities and Local Government (2006a) Strong and Prosperous Communities: The Local Government White Paper, London: DCLG. 
Department for Communities and Local Government (2006b) Thames Gateway Interim Plan Policy Framework, London: DCLG.

Department for Communities and Local Government (2007) Thames Gateway: The Delivery Plan, London: DCLG.

Department for Communities and Local Government (2008) Transforming Places, Changing Lives: A Framework for Regeneration, London: DCLG.

Eddington (2006) The Eddington Transport Study, London: HM Treasury.

Faludi, A. (2006) 'From European spatial development to territorial cohesion policy', Regional Studies, 40, 6, pp. 667-678.

Fothergill, S. (2005) 'A new regional policy for Britain', Regional Studies, 39, 5, pp. 659-667.

Gonzalez, S., Tomaney, J. and Ward, N. (2006) 'Faith in the city-region?', Town and Country Planning, November, pp. 315-317.

Gordon, I. (2006) 'Finding institutional leadership for regional networks: the case of London and the greater South East', in Salet, W. (ed) Synergy in Urban Networks, The Hague: Sdu Publishers, pp. 136-160.

Hall, P. (2009) 'Looking backward, looking forward: The city region of the mid-2 $1^{\text {st }}$ century' Regional Studies, (this issue)

Hall, P. and Pain, K. (2006) The Polycentric Metropolis, London: Earthscan.

Harding, A. (2006) 'Devolution in England: cause without a rebel?', in Salet, W. (ed) Synergy in Urban Networks, The Hague: Sdu Publishers, pp. 27-48.

Harding, A., Marvin, S. and Robson, B. (2006) A Framework for City-Regions, London: ODPM.

HCCPA (House of Commons Committee of Public Accounts) (2007) The Thames Gateway: Laying the Foundations, London: The Stationery Office, HC 693.

HCCLGC (House of Commons Communities and Local Government Committee) (2007) Is there a future for regional government?, London: The Stationery Office, HC 352-1

Healey, P. (2009) 'City-regions and place development', Regional Studies, (this issue)

HM Treasury (2006) The Importance of Cities to Regional Growth, Devolving Decision Making: 3 - Meeting the Regional Economic Challenge, London: HM Treasury.

HM Treasury (2007) Review of sub-national economic development and regeneration, London: HM Treasury.

HM Treasury (2008) The UK Economy: Addressing Long-Term Strategic Challenges, London: HM Treasury.

Hull, A. (1998) 'Spatial planning: The development plan as a vehicle to unlock development potential?', Cities, 15, 5, pp. 327-335.

John, P., Tickell, A. and Musson, S. (2005) 'Governing the mega-regions: governance and networks across London and the South East of England', New Political Economy, 10, 1, pp. 91-106.

Jonas, A. and Ward, K. (2007) 'Introduction to a debate on city-regions: New geographies of governance, democracy and social reproduction' International Journal of Urban and Regional Research, 31(1), pp. 169-78.

Jones, A., Williams, L., Lee, N. et al (2006) Ideopolis: Knowledge City-Region, London: The Work Foundation.

Keating, M. (1998) The New Regionalism in Western Europe: Territorial restructuring and political change, Cheltenham: Edward Elgar.

Kelly, R. (2006) Keynote speech to the Thames Gateway Forum, November. www.communities.gov.uk/thamesgateway/crossgatewaypriorities/ 
Kintrea, K. (2007) 'Policies and programmes for disadvantaged neighbourhoods: recent English experience', Housing Studies, 22, 2, pp. 261-282.

Lucas, K. (1998) 'Upwardly mobile: Regeneration and the quest for sustainable mobility in the Thames Gateway', Journal of Transport Geography, 6, 3, p. 211-225.

Lupton, R. (2003) Poverty Street: The Dynamics of Neighbourhood Decline and Renewal. Bristol: The Policy Press.

Marshall, A. and Finch, D. (2006) City Leadership: Giving City-Regions the Power to Grow, London: IPPR.

Medway Council (2005) Economic Development Strategy Review, Medway: Medway Council.

Medway Council (2006a) Medway Regeneration Framework 2006-2016, Medway: Medway Council.

Medway Council (2006b) Medway Renaissance 2006-2016: Technical Appendix, Medway: Medway Council.

NAO (National Audit Office) (2007) The Thames Gateway: Laying the Foundations, London: The Stationery Office, HC 526.

Neuman, M. and Hull, A. (2009) 'The futures of the city region', Regional Studies, (this issue)

New Local Government Network (2005) Seeing the Light: Next Steps for City Regions, London: NLGN.

ODPM (2003a) Sustainable Communities: Building for the Future, London: Office of the Deputy Prime Minister.

ODPM (2003b) Creating Sustainable Communities: Making it Happen, London: Office of the Deputy Prime Minister.

ODPM (2005) Sustainable Communities: Homes for All. A Five-Year Plan from the ODPM, London: Office of the Deputy Prime Minister.

OECD (2006) Competitive Cities in the Global Economy, Paris: OECD.

OECD (2007) Higher Education and Regions, Paris: OECD.

Oxford Brookes University (2006) Thames Gateway Evidence Review, London: DCLG.

Parkinson, M., Champion, T., Evans, R. et al (2006) State of the English Cities, London: ODPM.

Parr, J. B. (2005) 'Perspectives on the City-Region', Regional Studies, 39, pp. 555566.

Pike, A., Rodriguez-Pose, A. and Tomaney, J. (2006) Local and Regional Development, London: Routledge.

Prime Minister's Strategy Unit (2005) Improving the Prospects of People Living in Areas of Multiple Deprivation in England, London: PMSU.

Raco, M. (2005) 'A step change or a step back? The Thames Gateway and the rebirth of the Urban Development Corporation', Local Economy, 20, 2, pp. 141-153.

Rice, P., Venables, A. and Patacchini, E. (2006) 'Spatial determinants of productivity: Analysis for the regions of Great Britain', Regional Science and Urban Economics, 36, pp. 727-752.

Rydin, Y. (1998) 'The enabling local state and urban development: resources, rhetoric and planning in East London', Urban Studies, 35, 2, pp. 175-191.

Salet, W. (2006) 'How to cope with the metamorphosis of the city-region?', in Salet, W. (ed) Synergy in Urban Networks, The Hague: Sdu Publishers, pp. 11-26. 
Salet, W., Thornley, A. and Kreukels, A. (eds) (2003) Metropolitan Governance and Spatial Planning: Comparative Case Studies of European City Regions, London: Spon Press.

Scott, A. J. (ed) (2001) Global City Regions: Trends, Theory, Policy, Oxford: Oxford University Press.

Scott, A. J. and Storper, M. (2003) 'Regions, globalisation, development', Regional Studies, 37, pp. 579-93.

Titheridge, H. and Hall, P. (2006) 'Changing travel to work patterns in South East England', Journal of Transport Geography, 14, 1, p. 60-75.

Turok, I. (2004) 'Cities, regions and competitiveness', Regional Studies, 38, 9, pp.1069-1083.

Turok, I. and Bailey, N. (2004) 'The theory of polynuclear urban regions and its application to Central Scotland', European Planning Studies. Vol. 12, 3, pp.371-389.

Turok, I., Kearns, A., Flint, J. et al (2006) State of the English Cities: Social Cohesion Report, London: Department of Communities and Local Government.

Urban Task Force (2005) Towards a Stronger Urban Renaissance, London: UTF.

Wheeler, S. M. (2009) 'Regions, megaregions and sustainability', Regional Studies, (this issue)

\section{Acknowledgements}

The empirical work was originally undertaken as a city case study for the State of English Cities report. Considerable thanks are due to the 20 people working in senior positions in Medway who participated in lengthy interviews. Useful comments on an earlier draft were also received from John Parr, Mike Raco and two anonymous referees.

\section{Appendix 1: Methods}

The following people were interviewed during the course of the study in 2005. A draft report containing the main findings was submitted to the local authority and circulated among key respondents for factual corrections and comments.

Medway Council Leader

Director of Development and Environment

Director of Education and Leisure

Director of Public Health

Assistant Director of Economic Development

Assistant Director of Regeneration and Environment

Assistant Director of Leisure

Head of Urban Regeneration

Housing Strategy Manager

Research and Review Manager

Community Safety Manager

Local Strategic Partnership Coordinator

Senior Planning Official

Service Manager for Youth

Manager of JobCentre Plus

University of Greenwich Director of Regional Liaison

Racial Equality Council 
Ethnic Minority Forum

Local Planning Consultant

Primary Care Trust Chairman

The following reports and documents were also consulted for background and supporting information.

Audit Commission Comprehensive Performance Assessment Improvement Report to Medway Council for year ending 31/3/2004

Deakin, H. and Kingsley Smith, B. (2005) More of the Same? Response to draft SE Regional Plan

Kent and Medway Health Overview Profile

Kent and Medway NHS Annual Report 2002/03

Medway Community Safety Partnership (2004) Crime, Disorder and Drugs Audit

Medway Council (2002) Economic Development Plan 2002-07.

Medway Council (2002) Skills Framework.

Medway Council (2002) Local Public Service Agreement.

Medway Council (2003) Local Plan.

Medway Council (2003) 2001 Census: Key statistics and update.

Medway Council (2003) Employment and Employment Land in Medway.

Medway Council (2003) Property Price Report.

Medway Council (2004) Community Report and Plan 2004-2007.

Medway Council (2004) Medway Waterfront Renaissance Strategy.

Medway Council (2004) Creating a City of Culture 2004-2008.

Medway Council (2004) Performance Plan 2004/05.

Medway Council (2004) Comprehensive Performance Assessment: Qualitative Assessment Submission.

Medway Council (2004) Performance Indicator Tables 2004-5.

Medway Council (2005) Area-wide Inspection Self Evaluation Report.

Medway Council (2005) Economic Development Strategy Review.

Medway Primary Care Trust (2004) Analysis of the Index of Multiple Deprivation

Medway Racial Equality Council (2004) Annual Report

West Kent NHS Local Delivery Plan 2003-06 
Table A1: Employment by industrial sector (2006)

\begin{tabular}{|l|c|c|c|c|}
\hline & $\begin{array}{c}\text { Medway } \\
(\text { numbers })\end{array}$ & $\begin{array}{c}\text { Medway } \\
(\%)\end{array}$ & $\begin{array}{c}\text { South East } \\
(\%)\end{array}$ & $\begin{array}{c}\text { Britain } \\
(\%)\end{array}$ \\
\hline Total employee jobs & 86,300 & - & - & - \\
\hline Full-time & 57,400 & 66.5 & 69.3 & 68.9 \\
\hline Part-time & 28,900 & 33.5 & 30.7 & 31.1 \\
\hline Manufacturing & 8,800 & 10.2 & 8.8 & 10.9 \\
\hline Construction & 4,300 & 5.0 & 4.5 & 4.8 \\
\hline Services & 71,800 & 83.1 & 85.2 & 82.9 \\
\hline Distribution, hotels \& restaurants & 19,400 & 22.5 & 24.6 & 23.5 \\
\hline Transport \& communications & 4,600 & 5.3 & 6.0 & 5.9 \\
\hline Finance, IT, other business activities & 16,600 & 19.2 & 24.1 & 21.2 \\
\hline Public admin, education \& health & 25,800 & 29.8 & 25.4 & 26.9 \\
\hline Other services & 5,400 & 6.2 & 5.2 & 5.3 \\
\hline Tourism-related & 6,200 & 7.2 & 7.9 & 8.3 \\
\hline
\end{tabular}

Source: ONS Annual Business Inquiry employee analysis

Note: $\%$ is a proportion of total employee jobs

Table A2: Employment by occupation (2006/07)

\begin{tabular}{|l|c|c|c|c|}
\hline & $\begin{array}{c}\text { Medway } \\
\text { (numbers) }\end{array}$ & $\begin{array}{c}\text { Medway } \\
(\%)\end{array}$ & $\begin{array}{c}\text { South East } \\
(\%)\end{array}$ & $\begin{array}{c}\text { Britain } \\
(\%)\end{array}$ \\
\hline Soc 2000 major group 1-3 & 43,700 & 35.0 & 46.9 & 42.3 \\
\hline 1 Managers and senior officials & 14,000 & 11.2 & 17.5 & 15.1 \\
\hline 2 Professional occupations & 11,300 & 9.1 & 14.0 & 13.0 \\
\hline 3 Associate professional \& technical & 18,400 & 14.8 & 15.4 & 14.3 \\
\hline Soc 2000 major group 4-5 & 32,600 & 26.2 & 22.4 & 22.9 \\
\hline 4 Administrative \& secretarial & 16,700 & 13.4 & 12.4 & 12.0 \\
\hline 5 Skilled trades occupations & 15,900 & 12.8 & 10.0 & 10.9 \\
\hline Soc 2000 major group 6-7 & 22,500 & 18.1 & 15.2 & 15.7 \\
\hline 6 Personal service occupations & 11,400 & 9.1 & 8.0 & 8.1 \\
\hline 7 Sales and customer service occs & 11,200 & 9.0 & 7.2 & 7.6 \\
\hline Soc 2000 major group 8-9 & 25,400 & 20.4 & 15.3 & 18.7 \\
\hline 8 Process plant \& machine operatives & 11,000 & 8.8 & 5.2 & 7.2 \\
\hline 9 Elementary occupations & 14,400 & 11.5 & 10.2 & 11.5 \\
\hline
\end{tabular}

Source: ONS Annual Population Survey (April 2006-March 2007)

Note: \% is a proportion of all persons in employment 
Table A4: Workplace of Medway residents

\begin{tabular}{|l|c|c|c|c|}
\hline & $\begin{array}{c}\text { Professionals, } \\
\text { managers \& } \\
\text { employers } \\
(\%)\end{array}$ & $\begin{array}{c}\text { Intermediate and } \\
\text { technical } \\
\text { occupations, \& } \\
\text { self-employed } \\
(\%)\end{array}$ & $\begin{array}{c}\text { Routine and } \\
\text { semi-routine } \\
\text { occupations } \\
(\%)\end{array}$ & $\begin{array}{c}\text { Total } \\
\text { (numbers) }\end{array}$ \\
\hline London & 53.1 & 35.4 & 11.5 & 17,380 \\
\hline Kent & 36.6 & 33.0 & 30.4 & 26,332 \\
\hline Medway & 28.9 & 38.5 & 32.6 & 68,151 \\
\hline Elsewhere & 50.7 & 30.1 & 19.2 & 3,915 \\
\hline Total (\%) & 35 & 36.5 & 28.5 & $100 \%$ \\
Total (numbers) & $(40,559)$ & $(42,215)$ & $(33,004)$ & $(115,778)$ \\
\hline
\end{tabular}

Source: Population Census (2001)

Table A5: Origin of people who work in Medway

\begin{tabular}{|l|c|c|c|c|}
\hline & $\begin{array}{c}\text { Professionals, } \\
\text { managers \& } \\
\text { employers } \\
(\%)\end{array}$ & $\begin{array}{c}\text { Intermediate \& } \\
\text { technical } \\
\text { occupations, \& } \\
\text { self-employed } \\
(\%)\end{array}$ & $\begin{array}{c}\text { Routine and } \\
\text { semi-routine } \\
\text { occupations } \\
(\%)\end{array}$ & $\begin{array}{c}\text { Total } \\
\text { (numbers) }\end{array}$ \\
\hline Medway & 28.9 & 38.5 & 32.6 & 68,151 \\
\hline Elsewhere & 55.2 & 27.4 & 17.4 & 18,712 \\
\hline Total (\%) & 34.6 & 36.1 & 29.3 & $100 \%$ \\
Total (numbers) & $(30,038)$ & $(31,333)$ & $(25,492)$ & $(86,863)$ \\
\hline
\end{tabular}

Source: Population Census (2001)

\begin{tabular}{|l|c|l|c|}
\hline & Jobs density & & Jobs density \\
\hline Medway & 0.68 & Guildford & 1.00 \\
\hline Hastings & 0.71 & Peterborough & 1.00 \\
\hline Luton & 0.84 & Milton Keynes & 1.00 \\
\hline Southampton & 0.87 & Slough & 1.06 \\
\hline Brighton and Hove & 0.90 & Reading & 1.17 \\
\hline Portsmouth & 0.96 & South East England & $\mathbf{0 . 8 8}$ \\
\hline Maidstone & 0.99 & Britain & $\mathbf{0 . 8 4}$ \\
\hline
\end{tabular}

Source: ONS via NOMIS

Note: The jobs density is defined as the ratio of total employment to the working-age population 
Table A6: Qualifications (2006)

\begin{tabular}{|l|c|c|c|c|}
\hline & $\begin{array}{c}\text { Medway } \\
(\text { numbers })\end{array}$ & $\begin{array}{c}\text { Medway } \\
(\%)\end{array}$ & $\begin{array}{c}\text { South East } \\
(\%)\end{array}$ & $\begin{array}{c}\text { Britain } \\
(\%)\end{array}$ \\
\hline NVQ4 and above & 28,900 & 18.3 & 30.5 & 27.4 \\
\hline NVQ3 and above & 62,300 & 39.4 & 49.4 & 45.3 \\
\hline NVQ2 and above & 96,100 & 60.8 & 68.0 & 63.8 \\
\hline NVQ1 and above & 127,300 & 80.5 & 82.7 & 77.8 \\
\hline Other qualifications & 11,500 & 7.3 & 7.7 & 8.5 \\
\hline No qualifications & 19,200 & 12.2 & 9.6 & 13.8 \\
\hline
\end{tabular}

Source: ONS Annual Population Survey (Jan 2006-Dec 2006)

Note: $\%$ is a proportion of total working age population

Table 1: Economic indicators

\begin{tabular}{|l|c|c|c|}
\hline & Medway & South East & Britain \\
\hline Gross Value Added per head (2002) & 10,326 & 16,758 & 15,614 \\
\hline Average household income (2001/02) & $£ 19,500$ & $£ 24,740$ & $£ 21,170$ \\
\hline Gross hourly pay for f-t men* (2007) & $£ 11.93$ & $£ 13.02$ & $£ 12.14$ \\
\hline Gross hourly pay for f-t women* (2007) & $£ 9.69$ & $£ 10.86$ & $£ 10.48$ \\
\hline
\end{tabular}

Source: ONS via NOMIS and Medway Council (2006b)

Notes: * Earnings data are workplace based.

South East is the official region (i.e. excluding London)

Table 2: Labour market indicators (2006/07)

\begin{tabular}{|l|c|c|c|}
\hline & Medway (\%) & $\begin{array}{c}\text { South East } \\
(\%)\end{array}$ & Britain (\%) \\
\hline Employment rate & 76.5 & 78.3 & 74.2 \\
\hline Unemployment & 5.5 & 4.4 & 5.3 \\
\hline Key benefit claimants & 13.3 & 9.7 & 14.2 \\
\hline $\begin{array}{l}\text { Economically inactive wanting a } \\
\text { job }\end{array}$ & 7.3 & 5.4 & 5.5 \\
\hline
\end{tabular}

Source: ONS Annual Population Survey (April 2006-March 2007); DWP benefit claimants 
Table 3: Estimated investment required to deliver Medway's regeneration framework (2006-2016)

\begin{tabular}{|l|c|}
\hline Theme & Level of investment (£m) \\
\hline Housing & 835 \\
\hline Transport & 250 \\
\hline Culture & 250 \\
\hline Learning and skills & 185 \\
\hline Infrastructure & 150 \\
\hline Health & 140 \\
\hline Environment & 89 \\
\hline Economy & 85 \\
\hline Sports and leisure & 80 \\
\hline Town centres & 70 \\
\hline Tourism and heritage & 45 \\
\hline Social and community regeneration & 18 \\
\hline
\end{tabular}

Source: Medway Council, 2006a. 
Figure 1: Growth Areas in the South East

Source: ODPM, 2003b

Figure 2: Extent of Thames Gateway

Figure 3: Main settlements and development sites in Medway

http://mc.manuscriptcentral.com/cres Email: regional.studies@newcastle.ac.uk 
Figure 4: Medway Renaissance projects in the pipeline

- Rochester Riverside: This 30 hectare site is one of the flagship projects of the TG. The site has been cleared and a planning application for 2000 homes, two hotels, shops, restaurants, pubs and cafes was submitted in 2005 and approved in 2006. There will also be a river walk and some health and community space.

- Chatham Centre and Waterfront: A development brief has been prepared to expand and modernise the current Pentagon shopping centre to become a new commercial, cultural and civic centre. Three other neighbouring sites will be redeveloped - Waterfront, Brook and Station Gateway. Some 3500 new homes are expected. A new bus interchange will be created, a river walk and a regional cultural venue on the riverfront.

- $\quad$ Strood Riverside: This 10 hectare site has been acquired and a development brief prepared for 550 homes at high density. Watermill Wharf will provide space for social enterprise and be a feature point of Strood riverfront and river walk.

- Chatham Quays: A planning application for mixed uses including 300 homes has been approved, with a S106 Agreement under negotiation.

- Dickens World in Chatham: A themed visitor attraction and multi-screen cinema was opened in 2007. It aims to attract 300-400,000 visitors per year.

- St Mary's Island in Chatham: There are plans to develop 900 homes in addition to the 900 already built.

- $\quad$ Temple Waterfront: A development brief has been prepared for mixed uses including 500 homes.

- Strood and Gillingham town centres: A development framework and action plan are being prepared for some 650 new homes along with the growth of the evening economy, leisure and retail uses through improvements to the environment, road network and car parking.

- $\quad$ Former Akzo Nobel site in Gillingham: A development brief was adopted in 2004 for a mixed-use scheme including 800 homes on 8 hectares. Planning consent has subsequently been granted.

- $\quad$ Former Chattenden barracks: The Ministry of Defence has approved the sale of part of this site for some 5000 new homes and related community facilities (DCLG, 2007).

- Universities at Chatham: New and refurbished buildings for teaching, support services and student accommodation to create a more complete university campus in Chatham.

- An Innovation Centre in partnership with BAE Systems, local universities and others to accommodate high-tech manufacturing, spin-out companies and specialised business services.

Source: Compiled by the author from a variety of sources, including Medway Council (2006a). 
